\title{
Morphological, Chemical and Molecular Characterization of 'Old olive' (Olea europaea L.) from Montenegro
}

\author{
Mirjana Adakalic ${ }^{1 *}$, Biljana Lazovic ${ }^{1}$ \\ ${ }^{1}$ Univerzitet Crne Gore Biotehnicki fakultet, Podgorica, Montenegro
}

\begin{abstract}
Thousands of years of tradition of olive cultivation in Montenegro is witnessed with the 'Old olive' estimated to be more than 2000 years old. 'Old olive' draws attention to its genetic potential and the relation to the closest grown olive cultivars. Therefore, the aim of this paper was to give the basic description of 'Old olive' (through 20 morphological and 37 chemical properties) as well as to determine its DNA profile and to examine the closeness with major olive cultivar grown, $c v$. 'Žutica'. The obtained data showed the differences between examined samples. 'Old olive' started flowering (27. May) more than 10 days later than $\mathrm{cv}$. 'Žutica' (14. May), and began ripening 15 days later $\left(20^{\text {th }}\right.$ October and $5^{\text {th }}$ October, respectively). From 21 morphological parameters analysed all traits of fruit (weight $2.11 \mathrm{~g}$ in 'Old olive' and 3.55g in cv. 'Zutica'), and inflorescence density (6.39 versus 5.55) showed very significant and significant differences, respectively. The chemical properties also showed very significant differences in olive oil content in the fresh (11.28 versus 19.68\%) and dry matter (27.97 versus 47.78\%), and significant differences in the content of linolenic acid (0.76 versus $0.54 \mathrm{~g} / 100$ of FA and of campesterol (3.4 versus 3.1\%). Three out of eleven SSR markers (DCA05, DCA09, DCA16) distinguished obtained DNA fragments, and showed as important tool in differentiation of two samples. Further study of the 'Old olive' as a living memory of olive cultivation in Montenegro, should be to examine its relation with other ancient olive trees and local varieties.
\end{abstract}

Key words: 'Old olive' tree, morphology, oil, SSR, cv. ‘Žutica', Montenegro

*Author for correspondence: adakalic@yahoo.com 


\section{INTRODUCTION}

The survival of very ancient olive trees has been reported through the entire Mediterranean area. The ancient trees are the living proof of the very long tradition of olive cultivation. These trees have main genetic, agronomical, naturalistic, landscape and historical importance [ $\left.{ }^{1}\right]$. Thousands of years of tradition of olive cultivation in Montenegro is linked to the 'Old olive' (Fig. 1), the oldest exemplar in the region and beyond. 'Old olive' (in Montenegrin 'Stara maslina') is the name by which this tree is known among the people and registered as the 'monument' of nature since 1963. Its estimated age is of more than 2000 years $\left[{ }^{2}\right]$, recently confirmed $\left[{ }^{3}\right]$.

The 'Old olive' tree is a vital part of the visual and spiritual identity of the Montenegrin Coastal area, valuable evidence of ancient civilization in this area. The importance to take care of 'Old olive' passed down from generation to generation. Among people it is said that the tree is older than Christ, while the older people still remember the strict prohibition of removing leaves and cuttings from the tree, which contributed to its preservation until today. The place, where the 'Old olive' is situated, has always had a great socio-cultural significance for the area of Bar. It is believed that the place Mirovica was named after the meetings and counselling kept under the crown of the tree, with aim to make peace among people at loggerheads, and where 'giving faith' for omission of evil [ $\left.{ }^{4}\right]$. The last private owner of 'Old olive', bought it together with a large estate, in the thirties of $\mathrm{XX}^{\text {th }}$ century, and in sharing the estate with his brothers gave 20 other 'roots' (trees) of olive trees in exchange. During the Second World War the Italians wanted to buy the 'Old olive' tree for 2.5 million golden liras, but the owner did not accept the offer. In the mid-sixties 'Old olive' was recognized as 'general interest' and the Municipality of Bar brought it from the owner. Until the nineties of the $\mathrm{XX}^{\text {th }}$ century the olive oil processing company 'Primorka' was responsible for maintenance of 'Old olive' when it was overtaken by the City of Bar and stayed nowadays. The 'Old olive' tree had hard periods, one of which happened in the 60s of last century when, due to the people's negligence the part of the trunk was burnt down (Fig. 1A). Today, the 'Old olive' is an attractive tourist destination (Fig. 1D) and remains a lasting inspiration for native artists. Under the 'Old olive' tree, a trademark of Bar, various cultural events are held and most recognized are International Film Festival and the Days of poetry, awarded with the prize which symbolize the 'Old olive'. 

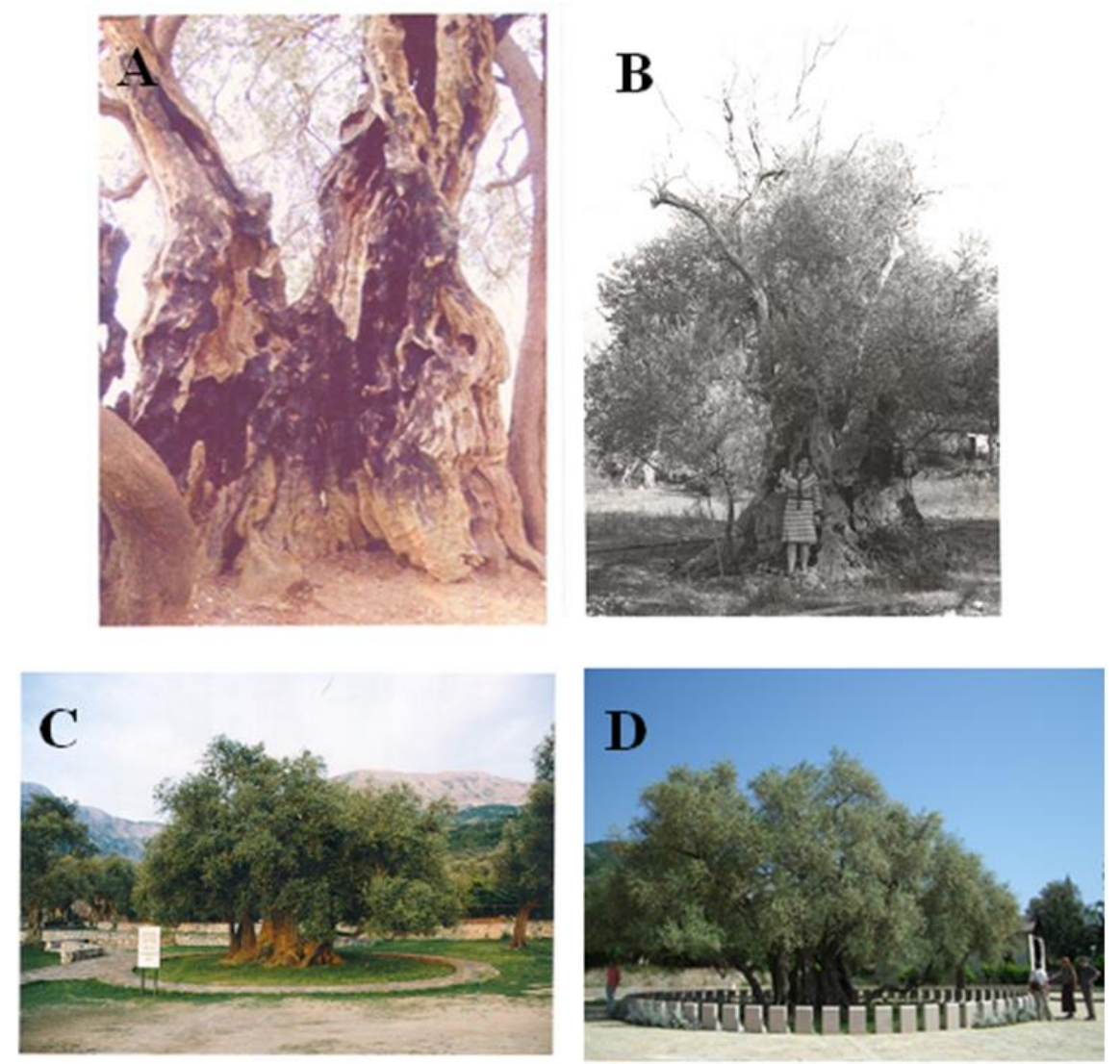

Figure 1. Recent history of 'Old olive' tree: A - Consequences of the fire occurred in the sixties are still obvious (photo from 2004); B -'Old olive' tree recovering from the fire (photo from 1972, $\left.{ }^{5}\right]$ ); C -The 'Old olive' tree on Mirovica in the end of $\mathrm{XX}^{\text {th }}$ century; D - Actual view of the 'Old olive' tree.

Beside historical and cultural significance, 'Old olive' draws attention to examine its genetic potential, interest indicated through the works on the old olive trees in other countries $\left[{ }^{6,7,8,9}\right]$. The age of this tree and the fact that is located in a monovarietal region, cause attention from morphological to molecular aspects. Classical approaches for identifying olive cultivars based on morphology $\left[{ }^{10}\right]$ provide a very useful tool for identification, but it has limitations because of environmental influences, and the need for extensive observations of mature plants. Therefore, DNA-based SSR markers as independent of the environment exhibit a higher degree of polymorphism and provide an opportunity for genetic characterization and biodiversity studies in olive $\left[{ }^{11,12}\right]$.

The presumption that the 'Old olive' is actually a rootstock on which it was grafted cv. 'Žutica', because the long-thought was that 'Old olive' is of 'Žutica' variety [ $\left.{ }^{5}\right]$, which developed from the root neck, after a fire burnt the plant mass. Such presumption opens many issues for more reasons as: on the same location around the 'Old olive' there are relatively old trees of 'Žutica' variety (500-800 of years) on their own roots; in the southern area of the Montenegro coast for a long time olives were propagated by separation of the shoots from the trunk base (root neck) with a part of the mother tree so called tubers (spheroblasts), which was abundant in 'Žutica' variety $\left[{ }^{13}\right]$. That seems contrary to the findings of Díez et al. $\left[{ }^{8}\right]$ and Barazani et al. $\left[{ }^{14}\right]$, which suggest that grafting pre-existing wild olives with olive cultivars was linked to the beginnings of olive growing. Another speculation on the origin of 'Old olive' lies in the traditional practice of planting a wild olive (oleaster), for better pollination. These pollinators are characterized with small fruit and poor quality oil. 
Along the way on answering if the 'Old olive' is a mother tree (or what is the relation) to other old trees grown in the area, this paper is to give the basic description of the 'Old olive' specimen and in comparison with major characteristics of the 'Žutica' cultivar.

\section{MATERIALS AND METHODS}

\section{Plant material}

'Old olive' tree is located on Mirovica near Bar, on $42^{\circ} 04^{\prime} 48.53^{\prime \prime}$ North, $19^{\circ} 07^{\prime} 45.96 "$ East, $47 \mathrm{~m}$ above sea level, in the Southern region, named Bar-subregion. In this area in the olive cultivation where predominate the indigenous variety 'Žutica' (around 98\%). Therefore, both samples were treated to belong to the prevalent cv. 'Žutica'. In order to evaluate potential relationship between 'Old olive' and cv. 'Žutica', morphological data of plant organs, chemical parameters of fruit and olive oil quality and their SSR profiles were compared. The trees were situated at the same location, to avoid possible environmental influence on the parameter measurements and observations.

\section{Morphological characteristics}

To provide more precise average values the data were collected during five years period (2012-2016). The measures were performed according to the olive descriptor $\left[{ }^{10,15}\right]$ used as standard in evaluation of the morphological and agronomic properties of olive varieties. Observation was performed on flowering (beginning and end of flowering, intensity and duration) and ripening (beginning and full) stages, and the number of days from end of flowering to the full ripening. For yield data, the fruits were harvested and measured in full ripening stage. From the plant organs the following properties of leaf (length, width and shape), internode length, inflorescences (length, number of flowers, number and percentage of imperfect flowers, inflorescence density), fruit (length, width, form, weight, pulp weight and percentage, pulp/endocarp ratio, and number of fruits in $1 \mathrm{~kg}$ ), and endocarp (length, width, form, weight) were measured.

For the fruit analysis a sample of 100 fruits was taken from each accession from all sides of the crown and from the mid treetop section. The fruits were at the beginning of ripening phase, reaching the full fruit size characteristic of 'Old olive' tree and of variety 'Žutica' trees. The harvested sample was divided into two sub-samples: one of 40 fruits was used for characterising the fruit and endocarp, while $100 \mathrm{~g}$ from the second subsample was used for determining moisture and dry matter.

\section{Olive oil analysis}

Olive oils were extracted from fruit samples (3-4 kg each sample) during three years period (2012-2014) from 'Old olive' tree (1) and cv. 'Žutica' (2), picked at full maturation (maturation index $=6-7$ ). Olive oil extracted on the laboratory olive mill (Abencor system) was used for further analyses.

Olive oils quality parameters were determined (free acidity, peroxide value, and specific coefficients of extinction) according to the Regulation EEC 2568/91 of the European Union Commission (Annex II, III and IX $\left[{ }^{16}\right]$ ). Fatty acids composition (Annex XA and Annex XB $\left[{ }^{16}\right]$ ), sterolic fraction (Annex V $\left[{ }^{16}\right]$ ), wax (Annex IV $\left[{ }^{16}\right]$ ) and total phenols content (determined colorimetrically using the Folin-Ciocalteu reagent $\left[{ }^{17}\right]$ ) were analysed. The oils were also tested by an organoleptic panel 
(according to the Panel test method (Annex XII $\left[{ }^{16}\right]$ ) to characterize the sensorial composition as well as nature and defects of the olive oils from 'Old olive' tree.

\section{Molecular analyses}

DNA was extracted from young leaves of 'Old olive' tree and cv. 'Žutica' with the Plant Mini Kit according to the manufacturer's instructions. The DNA analyses were performed using 11 SSRs developed for high levels of polymorphism: ssrOeUADCA03, ssrOeUA-DCA05, ssrOeUA-DCA09, ssrOeUA-DCA14, ssrOeUA-DCA16, ssrOeUA-DCA18 $\left[{ }^{18}\right]$; EMO90 $\left[{ }^{19}\right]$; GAPU71B, GAPU101, GAPU103A $\left[{ }^{20}\right]$ and UDO99-43 $\left[{ }^{21}\right]$. All these loci are included in the list of best SSR markers for cultivar fingerprinting $\left[{ }^{22}\right]$. Capillary electrophoresis was performed on an automated sequencer (ABI 3130 Genetic Analyzer Applied Biosystems, Foster City, CA, USA). Molecular data, fragment sizes were automatically calculated to two decimal places using the Gene Mapper 3.7 (Applied Biosystems).

\section{Data analysis}

To determine the significance between morphological parameters (leaf, inflorescence fruit and endocarp) and chemical composition of fruits of 'Old olive' tree and cv. 'Žutica', ANOVA, LSD test for materiality threshold of $P<0.05$ was used. The data were analysed in the software STATISTIX 7.0 (General AOV; Statistix 7, Analytical Software, Tallahassee, Florida, USA).

\section{RESULTS AND DISCUSSION}

\section{Morphological and biological characteristics}

Morphological characteristics are presented in the Figure 2 and Tables 1 and 2 . Beginning of flowering of 'Old olive' differs from the variety 'Žutica' and occurs on May 27, which is 13 days later than that of cv. 'Žutica' (May 14). Flowering lasts for 12 days and ends at the end of the first week of June (June 7). Flowering intensity varies from low to abundant, in average medium extensive (grade 3). Fruit ripening begins in the second half of October, 15 days later than in 'Žutica', and full ripening when most of the fruits were fully coloured, stands in mid-November. From the end of flowering to full ripening of the 'Old olive' was 161 days, similar to 'Žutica' (166 days). The yield of 'Old olive' is regular, medium to high (around $120 \mathrm{~kg}$ ), and thanks to the size of the tree $\left[{ }^{23}\right]$, it is much more productive than the average tree of 'Žutica' variety $(40 \mathrm{~kg})$. 

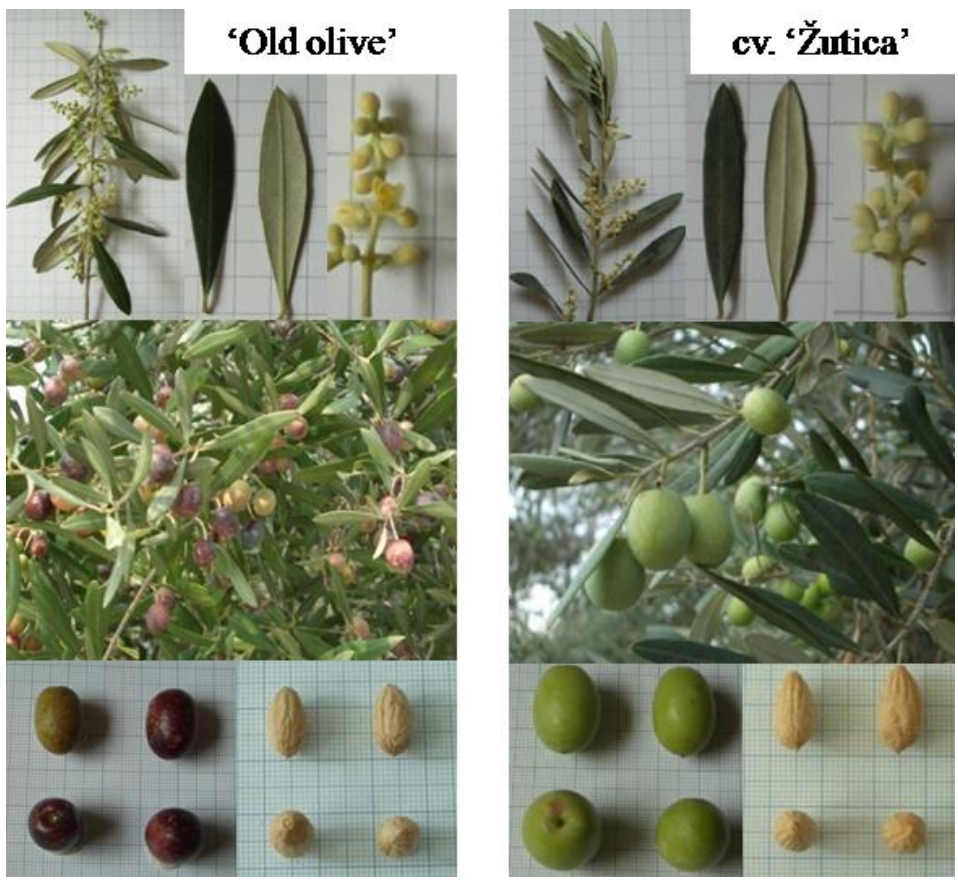

Figure 2. Morphological description of 'Old olive' tree and cv. 'Žutica' trees organs.

Table 1. Flowering and ripening period of 'Old olive' and cv. 'Žutica' trees.

\begin{tabular}{lcc}
\hline Biological characteristics & 'Old olive' & cv. ‘Žutica' \\
\hline Beginning of flowering & May 27 & May 14 \\
End of flowering & June 7 & May 25 \\
Flowering intensity & 3 & 4 \\
Duration of flowering & 12 days & 11 days \\
Beginning of ripening & October 20 & October 5 \\
Full ripening & November 15 & November 7 \\
Days from end of flowering to full ripening & 161 & 166 \\
\hline
\end{tabular}

The biometric data of olive organs is very important to discriminate olive cultivars $\left[{ }^{10,24,25}\right]$. The measurements of 21 parameters of olive leaf, inflorescence, fruit and endocarp are presented in Table 2. Very significant differences between two samples were shown in the fruit trait and significant in inflorescence density.

The leaf of 'Old olive' is elliptic-lancelet, medium long and narrow, with a maximum diameter in the middle. Colour of the leaf surface is green and grey-green-silvery on the reverse side. The internodes of 'Old olive' are medium-long $(1.66 \mathrm{~cm})$; inflorescences are compact, medium in length with a medium number of flowers (18.35), while cv. 'Žutica' has a low number of flowers (15.13) and lower density of flowers in bloom. There was no significant difference in number of perfect flowers although their proportion varies with inflorescence, accessions and the prevailing environmental conditions $\left[{ }^{26}\right]$. Number of imperfect flowers was similar and low (3.96 and 3.34 , respectively) $\left[{ }^{10}\right]$, and with no influence to the yield, since if $1 \%$ to $2 \%$ of flowers set the fruit is enough for a good yield $\left[{ }^{27}\right]$.

The fruit of both samples belong to the medium category according to the olive descriptor $\left[{ }^{10}\right]$. However the fruit 'Old olive' is smaller $(2.11 \mathrm{~g})$, oval, symmetric, with a rounded base, peak without bulge and with lots of big lenticels on the green fruit, unlike the cv. 'Źutica' $(3,55 \mathrm{~g})$ that has few tiny lenticels (Lazovic et al., 2016). Pulp/endocarp ratio was much higher in cv. 'Žutica' (7.57) than in 'Old olive' (4.09) and belong to the different categories $\left[{ }^{28}\right]$, very high and high, respectively. Fruit 
parameters of two accessions are statistically significantly different at $\mathrm{P}<0.05$, confirming that differences in the fruit size are mainly of genetic origin $\left[{ }^{29}\right]$. The endocarp traits, although have been recognised as the most affective among morphological data, due to their high discrimination capacity and low sensitivity on environmental influence [ ${ }^{1}$, did not show significant differences between the two analysed samples. This might also be the reason of the lack in distinguish these two samples in the past. 'Old olive' endocarp is elliptical, medium $(0.41 \mathrm{~g})$, symmetric, rounded top and base, smooth surfaces with a high number of grooves evenly divided. The difference, however is observed visually (Fig. 2), especially in the prominence of the base and the largest diameter in cv. 'Zutica' which is closer to the top of the endocarp.

Table 2. Morphological characteristics of leaves, inflorescences, fruits and endocarps from 'Old olive' tree and cv. 'Žutica' trees.

\begin{tabular}{|c|c|c|c|c|}
\hline Plant organ & 'Old olive' tree & cv. 'Žutica' & LSD F-value $^{\mathrm{a}}$ & $P$-value \\
\hline \multicolumn{5}{|l|}{ Leaves } \\
\hline Leaf length $(\mathrm{cm})$ & $5.84 \pm 0.27^{\mathrm{b}}$ & $5.80 \pm 0.31$ & $0.04 \mathrm{~ns}$ & 0.8467 \\
\hline Leaf width $(\mathrm{cm})$ & $1.23 \pm 0.10$ & $1.25 \pm 0.06$ & $0.21 \mathrm{~ns}$ & 0.6578 \\
\hline Shape (L/W) & $4.76 \pm 0.39$ & $4.65 \pm 0.26$ & $0.47 \mathrm{~ns}$ & 0.5066 \\
\hline Internode length & $1.66 \pm 0.14$ & $1.54 \pm 0.20$ & $1.11 \mathrm{~ns}$ & 0.3171 \\
\hline \multicolumn{5}{|l|}{ Inflorescences } \\
\hline Length $(\mathrm{cm})$ & $2.87 \pm 0.39$ & $2.72 \pm 0.40$ & $0.40 \mathrm{~ns}$ & 0.5418 \\
\hline Number of flowers & $18.35 \pm 1.86$ & $15.13 \pm 3.36$ & $3.71 \mathrm{~ns}$ & 0.0831 \\
\hline Number of imperfect flowers & $3.96 \pm 0.79$ & $3.34 \pm 2.20$ & $0.36 \mathrm{~ns}$ & 0.5592 \\
\hline Imperfect flowers (\%) & $21.60 \pm 4.83$ & $22.04 \pm 8.80$ & $0.02 \mathrm{~ns}$ & 0.8792 \\
\hline $\begin{array}{l}\text { Inflorescence density } \\
\text { (flowers/length) }\end{array}$ & $6.39 \pm 0.41$ & $5.55 \pm 0.68$ & $6.43 *$ & 0.0295 \\
\hline \multicolumn{5}{|l|}{ Fruits } \\
\hline Length $(\mathrm{cm})$ & $1.94 \pm 0.07$ & $2.19 \pm 0.11$ & $20.50 * *$ & 0.0011 \\
\hline Width $(\mathrm{cm})$ & $1.38 \pm 0.04$ & $1.68 \pm 0.04$ & $126.33 * *$ & 0.0000 \\
\hline Form (L/W) & $1.40 \pm 0.03$ & $1.31 \pm 0.04$ & $18.25 * *$ & 0.0016 \\
\hline Weight $(\mathrm{g})$ & $2.11 \pm 0.18$ & $3.55 \pm 0.28$ & $98.85 * *$ & 0.0000 \\
\hline Pulp weight (g) & $1.70 \pm 0.14$ & $3.13 \pm 0.24$ & $136.31 * *$ & 0.0000 \\
\hline Pulp percentage in fruit & $80.35 \pm 0.96$ & $88.33 \pm 0.72$ & $272.64 * *$ & 0.0000 \\
\hline Pulp/endocarp ratio & $4.09 \pm 0.25$ & $7.57 \pm 0.51$ & $193.52 * *$ & 0.0000 \\
\hline Fruits in $1 \mathrm{~kg}(\mathrm{n})$ & $474 \pm 41.11$ & $282 \pm 22.82$ & $109.69 * *$ & 0.0000 \\
\hline \multicolumn{5}{|l|}{ Endocarp } \\
\hline Length $(\mathrm{cm})$ & $1.38 \pm 0.04$ & $1.39 \pm 0.06$ & $0.05 \mathrm{~ns}$ & 0.8339 \\
\hline Width (cm) & $0.72 \pm 0.03$ & $0.74 \pm 0.02$ & $2.68 \mathrm{~ns}$ & 0.1329 \\
\hline Form (L/W) & $1.94 \pm 0.09$ & $1.87 \pm 0.07$ & $1.65 \mathrm{~ns}$ & 0.2278 \\
\hline Weight $(\mathrm{g})$ & $0.41 \pm 0.04$ & $0.41 \pm 0.04$ & $0.00 \mathrm{~ns}$ & 0.9854 \\
\hline
\end{tabular}

${ }^{a}$ LSD Least Significant Difference test F-values.**Significant at $\mathrm{P}>0.01$; ${ }^{*}$ Significant at $\mathrm{P}>0.05 ;$; $\mathrm{s}-$ not significant $(\mathrm{P}<0.05)$.

${ }^{\mathrm{b}}$ Mean \pm S.D.

\section{Chemical characteristics of fruit}

Basic parameters of 'Old olive' fruit composition (Table 3) showed that the most important parameter, oil content in the fruit, is according to the descriptor very low in fresh matter $(11.28 \%)$ and dry matter $(27.97 \%)$, and significantly differ $(P<0.05)$ from the cv. 'Žutica', with an average of around $20 \%$ oil in the fruit $\left.{ }^{30,31}\right]$. According to Malheiro et al. $\left[{ }^{32}\right]$ fat content in olives is mainly influenced by the olive variety and the maturation degree, since olives were picked at full maturation (6-7 index), fat was completely formed in the fruits. Furthermore, the differences found in fat content are important to differentiate olive samples since according to Di Bella et al. $\left[{ }^{33}\right]$ fat content in olive fruits is regulated by genetic factors, highlighting differences between olive cultivars. 
Table 3. Chemical composition of fruits (g/100 g of fruits) from 'Old olive' and cv. 'Zutica' trees.

\begin{tabular}{lcccc}
\hline Fruit composition & 'Old olive' tree & cv. 'Žutica' & LSD F-value & P-value \\
\hline Dry matter & $40.33 \pm 2.71^{\mathrm{b}}$ & $41.18 \pm 2.41$ & $0.28 \mathrm{~ns}$ & 0.6134 \\
Humidity (\%) & $59.67 \pm 2.71$ & $58.82 \pm 2.41$ & $0.28 \mathrm{~ns}$ & 0.6134 \\
Oil in fresh matter & $11.28 \pm 2.22$ & $19.68 \pm 0.82$ & $62.83 * *$ & 0.0000 \\
Oil in dry matter & $27.97 \pm 3.82$ & $47.78 \pm 3.86$ & $68.18 * *$ & 0.0000 \\
\hline${ }^{a}$ LSD Least Significant Difference test F-values.**Significant at P>0.01; *Significant at P>0.05; ns-not significant $(\mathrm{P}<0.05)$. \\
b ${ }^{\mathrm{b}}$ Mean \pm S.D.
\end{tabular}

\section{Chemical characteristics of oil}

The prevalent cv. 'Žutica' enables production of mono-varietal oil. However, different cultivars or biodiversity of olive trees is the source of value which has to be recognised and preserved $\left[{ }^{34}\right]$. The research on biodiversity can help us to get oils with different taste which can satisfy demanding consumers $\left[{ }^{35}\right]$. In spite of the increasing appreciation of typical extra virgin olive oils, based on use of local traditional varieties, very few studies have focused on the genetic characterization of olive cultivars of regional or local interest $\left.{ }^{36}\right]$. The olive oils extracted from fruits of 'Old olive' and cv. 'Žutica' were analyzed regarding their quality parameters (Table 4), fatty acids and sterolic profiles (Tables 5 and 6 respectively). Regarding quality the oils from both 'Old olive' and cv. 'Žutica' are of good quality, with a low content of free fatty acids $(0.31$ and $0.45 \%$ respectively) and a low peroxide number ( 4.9 and 7.03 meq. $\mathrm{O}_{2} / \mathrm{kg}$, respectively). Even more, the results of specific extinction coefficients $\mathrm{K}_{232}$ and $\mathrm{K}_{270}$, as well as $\Delta \mathrm{K}$, presented good values. According to the data obtained for the quality parameters of olive oils from the studied samples complied with the Regulation limits for the extra virgin olive $\left[{ }^{37}\right]$.

Table 4. Quality parameters of olive oils from 'Old olive' and cv. 'Žutica' trees.

\begin{tabular}{lcccc}
\hline Quality parameter & 'Old olive' tree & cv. 'Žutica' & LSD F-value $^{\mathbf{a}}$ & $\boldsymbol{P}_{\text {-value }}$ \\
\hline Free acidity (\%) & $0.31 \pm 0.09^{\mathrm{b}}$ & $0.45 \pm 0.25$ & $0.84 \mathrm{~ns}$ & 0.4111 \\
Peroxide value (meq. $\mathrm{O}_{2} / \mathrm{kg}$ of oil) & $4.90 \pm 1.60$ & $7.03 \pm 0.32$ & $5.13 \mathrm{~ns}$ & 0.0863 \\
$\mathrm{~K}_{232}$ & $1.69 \pm 0.27$ & $1.60 \pm 0.12$ & $0.25 \mathrm{~ns}$ & 0.6417 \\
$\mathrm{~K}_{270}$ & $0.11 \pm 0.01$ & $0.06 \pm 0.00$ & $27.84 * *$ & 0.0062 \\
$\Delta \mathrm{K}$ & $-0.004 \pm 0.0002$ & $-0.002 \pm 0.0005$ & $3.77 \mathrm{~ns}$ & 0.1242 \\
\hline
\end{tabular}

${ }^{\mathrm{a}}$ LSD Least Significant Difference test F-values.**Significant at $\mathrm{P}>0.01$; *Significant at $\mathrm{P}>0.05$; ns - not significant $(\mathrm{P}<0.05)$.

${ }^{\mathrm{b}}$ Mean \pm S.D.

Fatty acid composition of the oil (Table 5) depends on genotype and indicates a high content of oleic acid (average 73.03\%), similar to previously obtained in Leccino $(73,8 \%)$ by Lazovic et al. ${ }^{[34}$. The contents of miristic, behenic, eureic and lignoceric acids were not reported, and the trans forms were absent in the oils of both specimen examined. Differences in oil of 'Old olive', especially the higher content of palmitic, margaric, margaroleic and linolenic acids, and lower content of palmitoleic stearic, oleic, linoleic, arachidic and gadoleic acids, were observed in comparison to the oil of cv. 'Žutica'. The differences found in fatty acids profile are important tools for varietal authentication. Fatty acids profiles could be used as fingerprints of olive varieties $\left[{ }^{38}\right]$, processed table olives $\left[{ }^{32}\right]$ and in olive oils as well $\left[{ }^{39,40}\right]$. Therefore, the obtained data in the fatty acids profile of 'Old olive' and cv. 'Žutica' could be indicative that cv. 'Žutica' is not provenience from 'Old olive'. Results obtained of fatty acids analysis are in conformity to those defined by the more recent European Regulation $\left[{ }^{41}\right]$. 
Table 5. Fatty acids composition (g/100g of fatty acids) in olive oils from 'Old olive' and cv. 'Žutica' trees.

\begin{tabular}{|c|c|c|c|c|}
\hline Fatty acids & 'Old olive' tree & cv. 'Žutica' & LSD F-value $^{\mathbf{a}}$ & $P$-value \\
\hline Palmitic $\left(\mathrm{C}_{16: 0}\right)$ & $13.62 \pm 1.75^{\mathrm{b}}$ & $12.61 \pm 0.77$ & $1.70 \mathrm{~ns}$ & 0.2191 \\
\hline Palmitoleic $\left(\mathrm{C}_{16: 1}\right)$ & $1.07 \pm 0.11$ & $1.19 \pm 0.30$ & $1.01 \mathrm{~ns}$ & 0.3371 \\
\hline Margaric $\left(\mathrm{C}_{17: 0}\right)$ & $0.23 \pm 0.13$ & $0.20 \pm 0.17$ & $0.12 \mathrm{~ns}$ & 0.7342 \\
\hline Margaroleic $\left(\mathrm{C}_{17: 1}\right)$ & $0.26 \pm 0.19$ & $0.21 \pm 0.15$ & $0.28 \mathrm{~ns}$ & 0.6079 \\
\hline Stearic $\left(\mathrm{C}_{18: 0}\right)$ & $2.76 \pm 0.70$ & $3.29 \pm 0.39$ & $2.62 \mathrm{~ns}$ & 0.1339 \\
\hline Oleic $\left(\mathrm{C}_{18: 1}\right)$ & $72.85 \pm 1.39$ & $73.21 \pm 0.51$ & $0.35 \mathrm{~ns}$ & 0.5655 \\
\hline Linoleic $\left(\mathrm{C}_{18: 2}\right)$ & $7.96 \pm 0.66$ & $8.10 \pm 1.32$ & $0.06 \mathrm{~ns}$ & 0.8178 \\
\hline Linolenic $\left(\mathrm{C}_{18: 3}\right)$ & $0.76 \pm 0.17$ & $0.54 \pm 0.09$ & $7.42 *$ & 0.0198 \\
\hline Arachidic $\left(\mathrm{C}_{20: 0}\right)$ & $0.30 \pm 0.05$ & $0.38 \pm 0.04$ & $7.78 *$ & 0.0176 \\
\hline Gadoleic $\left(\mathrm{C}_{20: 1}\right)$ & $0.20 \pm 0.11$ & $0.29 \pm 0.14$ & $1.82 \mathrm{~ns}$ & 0.2042 \\
\hline MUFA $^{\mathrm{c}}$ & $74.38 \pm 1.25$ & $74.90 \pm 0.63$ & $0.84 \mathrm{~ns}$ & 0.3784 \\
\hline PUFA $^{\mathrm{d}}$ & $8.72 \pm 0.72$ & $8.63 \pm 1.34$ & $0.02 \mathrm{~ns}$ & 0.8828 \\
\hline $\mathrm{SFA}^{\mathrm{e}}$ & $16.91 \pm 1.28$ & $16.47 \pm 0.82$ & $0.52 \mathrm{~ns}$ & 0.4876 \\
\hline trans fatty acids & n.d. ${ }^{\mathrm{f}}$ & n.d. & & \\
\hline \multicolumn{5}{|c|}{$\begin{array}{l}{ }^{\mathrm{a}} \text { LSD Least Significant Difference test F-values. } * * \text { Significant at } \mathrm{P}>0.01 ; * \text { Significant at } \mathrm{P}>0.05 ; \text { ns }- \text { not significant }(\mathrm{P}<0.05) \\
\mathrm{b} \text { Mean } \pm \text { S.D. } \\
{ }^{\mathrm{c}} \text { monounsaturated fatty acids } \\
\mathrm{d} \text { polyunsaturated fatty acids } \\
\text { e saturated fatty acids }\end{array}$} \\
\hline
\end{tabular}

Sterol fraction of olive oils from 'Old olive' and cv. 'Žutica' is presented in Table 6. $\beta$-sitosterol was the main sterol found (around 94\%) in both olive oils studied. There was no evidence of brassicasterol content, 24-methyl cholesterol and $\Delta$-7-campesterol. The content of campesterol was significantly higher than in the oil of 'Žutica'. Again, similarly to fatty acids profile, sterolic fraction can also be used as a chemical marker of olive varieties as observed by several studies $\left[{ }^{42,43}\right]$, confirming that sterolic composition of oils varies on the variability of gene expression $\left[{ }^{44}\right]$ and of good adaptation of the autochthonous accesssions to the local environment $\left[{ }^{45}\right]$.

Table 6. Composition of the sterolic fraction of olive oils from 'Old olive' and cv. 'Žutica' trees.

\begin{tabular}{|c|c|c|c|c|}
\hline Sterols (\%) & 'Old olive' tree & cv. 'Žutica' & LSD F-value ${ }^{a}$ & $P$-value \\
\hline Cholesterol & $0.3 \pm 0.09^{b}$ & $0.3 \pm 0.05^{\mathrm{a}}$ & $0.01 \mathrm{~ns}$ & 0.9315 \\
\hline Campesterol & $3.4 \pm 0.17$ & $3.1 \pm 0.10$ & $8.42 *$ & 0.0337 \\
\hline Campestanol & $0.2 \pm 0.09$ & $0.2 \pm 0.05$ & $0.41 \mathrm{~ns}$ & 0.5517 \\
\hline Stigmasterol & $1.0 \pm 0.38$ & $1.4 \pm 0.37$ & $2.46 \mathrm{~ns}$ & 0.1773 \\
\hline$\Delta-5,23$-stigmastadienol & $0.4 \pm 0.25$ & $0.4 \pm 0.20$ & $0.09 \mathrm{~ns}$ & 0.7796 \\
\hline Clerosterol & $1.0 \pm 0.08$ & $1.0 \pm 0.05$ & $0.73 \mathrm{~ns}$ & 0.4319 \\
\hline$\beta$-sitosterol & $81.8 \pm 1.58$ & $81.5 \pm 0.45$ & $0.09 \mathrm{~ns}$ & 0.7737 \\
\hline Sitostanol & $0.6 \pm 0.34$ & $0.5 \pm 0.05$ & $0.45 \mathrm{~ns}$ & 0.5334 \\
\hline$\Delta$-5-avenasterol & $10.0 \pm 1.36$ & $10.3 \pm 0.72$ & $0.15 \mathrm{~ns}$ & 0.7134 \\
\hline$\Delta-5,24$-stigmastadienol & $0.5 \pm 0.17$ & $0.4 \pm 0.05$ & $0.62 \mathrm{~ns}$ & 0.4665 \\
\hline$\Delta$-7-stigmastenol & $0.2 \pm 0.05$ & $0.2 \pm 0.05$ & $0.10 \mathrm{~ns}$ & 0.7663 \\
\hline$\Delta$-7-avenasterol & $0.4 \pm 0.08$ & $0.5 \pm 0.05$ & $3.08 \mathrm{~ns}$ & 0.1395 \\
\hline$\beta$-sitosterol total (sum: $1-6$ ) & $94.2 \pm 0.55$ & $94.1 \pm 0.68$ & $0.14 \mathrm{~ns}$ & 0.7275 \\
\hline Eritrodiol+Uvaol & $1.9 \pm 0.25$ & $1.8 \pm 0.44$ & $0.16 \mathrm{~ns}$ & 0.7125 \\
\hline
\end{tabular}

${ }^{a}$ LSD Least Significant Difference test F-values. **Significant at $\mathrm{P}>0.01$; *Significant at $\mathrm{P}>0.05$; ns-not significant $(\mathrm{P}<0.05)$.

${ }^{\mathrm{b}}$ Mean \pm S.D.

No difference in wax content (data not shown) among examined oils of 'Old olive' and cv. 'Žutica' was found (111 and $112 \mathrm{mg} / \mathrm{kg}$, respectively). Higher wax content was reported by Piscopo et al. $\left[{ }^{44}\right]$, with possible explanation of stronger response of examined samples to environmental factors as heat, humidity and irradiance, also 
reported in hotter climates $\left[{ }^{46}\right]$. Total polyphenols (data not shown) were slightly higher in 'Old olive' $(140 \mathrm{mg} / \mathrm{kg})$ than in cv. 'Žutica' $(120 \mathrm{mg} / \mathrm{kg})$. Both the oils of 'Old olive' and cv. 'Žutica' have a relative low polyphenol content under the Bar climatic conditions, and much lower than in Leccino $\left.(195 \mathrm{mg} / \mathrm{kg}){ }^{34}\right]$. Furthermore, since olives were collected at full maturation, low values of polyphenols are expected, since polyphenols decrease during olive maturation.

According to the sensory panel evaluation the flavour of 'Old olive' oils is characterized to have a distinct bitterness, which is also different from the oil of cv. 'Žutica', which is only slightly bitter. However, both oils are of good sensory properties.

\section{Molecular analysis}

The application of molecular tools in this research was to overcome the limitations of morphological analyses. Molecular analysis has also been able to identify cases of errors among accessions due to the mislabelling, propagation mistakes etc. [ $\left.{ }^{1}\right]$. Molecular identification of some ancient olive trees has demonstrated that they are remains of ancient olive cultivation and often represent unknown genotypes $\left[{ }^{47,8}\right]$. However, these trees should undergo an overall survey and a molecular together with agronomic evaluation. In our study, the molecular analysis with eleven SSR primers showed differences between 'Old olive' and cv. 'Žutica' (Table 7). The obtained DNA fragments were distinguished by primers DCA05, DCA09, DCA16. Also a single fragment difference was obtained in cv. 'Žutica' variety with DCA03, DCA18, EMO90, GAPU71B, and GAPU103A primers. Other primers gave the same fragments for both of the tested samples. After all, majority of primers applied distinguished samples analysed as two distant genotypes, confirming and emphasizing the differences showed with morphological and chemical analyses.

Table 7. Genotype profiles from 'Old olive' and cv. 'Žutica' trees obtained with 11 SSRs primers.

\begin{tabular}{lcc}
\hline SSRs primer & 'Old olive' tree & cv. 'Žutica' \\
\hline DCA03 & $232-239$ & $232-243$ \\
DCA05 & $220-220$ & $202-202$ \\
DCA09 & $192-206$ & $204-204$ \\
DCA14 & $177-189$ & $177-189$ \\
DCA16 & $148-152$ & $152-156$ \\
DCA18 & $179-179$ & $171-179$ \\
EMO90 & $186-188$ & $184-188$ \\
GAPU71B & $124-124$ & $124-127$ \\
GAPU 101 & $190-198$ & $190-198$ \\
GAPU103A & $178-178$ & $178-182$ \\
UDO99-043 & $180-180$ & $180-180$ \\
\hline
\end{tabular}

Taking into account the analysis presented in this paper, and additional parameters such as adaptation to environmental conditions, productivity, estimated age $\left[{ }^{3}\right]$, and olive oil quality, 'Old olive' represent very interesting genotype that should be safeguarded as original mother plant, which can be propagated and conserve and evaluated in the collections and field plots.

\section{CONCLUSION}

The 'Old olive' is the oldest olive tree of numerous ancient olive trees in Montenegro. It represents valuable specimen in olive genetic resources and makes this small country comparable to the much larger countries. Ancient trees, as the 'Old olive', 
represent the result of the centuries of experience in their productive behaviour or a high degree of environmental compatibility $\left[{ }^{47}\right]$. They are very useful for creating database/catalogue and to locate the hotspot areas of ancient olives in order to avoid losing forever this priceless olive germplasm $\left[{ }^{1}\right]$. Outstanding performance of the 'Old olive' makes its agronomic evaluation very useful with possibility to involve it in the breeding program in the future.

The molecular/SSR markers application was useful in proving the difference between 'Old olive' and cv. 'Žutica', showed to some extent with morphological and chemical analyses. Results clearly showed that treating 'Old olive' as of the same as cv. 'Žutica' was an example of homonymy. Thus, further analyses of the origin of the 'Old olive' and its relation to the local germplasm should be a future task. Important would be to continue research on uncharacterised olive samples from ancient trees which are still grown by the local farmers. This study also gives valuable data about the morphological and chemical characterization of 'Old olive' and cv. 'Žutica'. This is important for 'Old olive' which is a living memory of olive cultivation in Montenegro and the heritage that needs to be preserved, maintained and valorised at all levels.

\section{AKNOWLEDGEMENT}

This research was supported by the Ministry of Science of Montenegro through national research projects and projects of bilateral cooperation between Montenegro and Slovenia.

\section{REFERENCES}

1. Belaj A, Gurbuz Veral M, Sikaoui H, Moukhli A, Khadari B, Mariotti R, Baldoni L. Olive genetic resources, in E. Rugini et al. (eds): The olive genome, Compendium of plant genomes. Springer. 2016;27-54.

2. Miranović K. Elajografska proučavanja nekih introdukovanih stonih sorti maslina gajenih u Crnogorskoj suptropskoj zoni. Jugosl Vocar. 1988;22:356-371.

3. Alković Ć. Determining the age of olive trees in order to improve Montenegrin olive oil brand. VIII International olive Symposium, Book of abstracts. 2016; p.79.

4. Zadro B, Perica S, Bakarić P, Bjeliš M, Brekalo B, Bulimbašić-Botteri, et al. Maslina i maslinovo ulje A-Ž. Naklada ZADRO Zagreb. 2007;279.

5. Miranović K. Izučavanje elajografskih karakteristika masline cv. Žutice i njenog reagovanja na primijenjenu elajotehniku. Doktorska disertacija, Poljoprivredni fakultet Sarajevo. 1974;173.

6. Miljković I, Žužić I, Pucci C, Baldoni L, Mariotti M, Cultrera NGM. Molecular characterization of an ancient Olea europaea tree located on the Brijuni islands (Croatia) by SSR markers analysis, Pom Croatica. 2010;16(1-2):3-11.

7. Durgac C, Kiyga Y, Ulas M. Comparative molecular analysis of old olive (Olea europaea L.) genotypes from eastern Mediterranean Region of Turkey. Afr J Biotechnol. 2010;9:428-433.

8. Díez MC, Trujillo I, Barrio E, Belaj A, Barranco D, Rallo L. Centennial olive trees as a reservoir of genetic diversity. Ann Bot. 2011;108(5):797-807.

9. Arnan X, López BC, Martínez-Vilalta J, Estorach M, Poyatos R. The age of monumental olive trees (Olea europaea) in northeastern Spain. Dendrochronologia 2012;30(1):11-14.

10. Barranco D, Cimato A, Fiorino P, Rallo L, Touzani A, Castañeda C, Serafini F, Trujillo I. World Catalogue of Olive Varieties. Consejo Oleícola Internacional, Madrid, 2000;pp.360.

11. Belaj A, Satovic Z, Cipriani G, Baldoni L, Testolin R, Rallo L, Trujillo I. Comparative study of the discriminating capacity of RAPD, AFLP and SSR markers and of their effectiveness in establishing genetic relationships in olive. Theor Appl Genet. 2003;107:736744.

12. Bandelj D, Javornik B. Microsatellites as a powerful tool for identification of olive (Olea europaea L.) planting material in nurseries. Ann Ser Hist Nat. 2007;17:133-138. 
13. Drecun V. Stanje i problematika maslinarstva na Crnogorskom primorju. Poljoprivreda i šumarstvo/AgricultForest. 1956;2(2):91-100.

14. Barazani O, Westberg E, Hanin N, Dag A, Kerem Z, Tugendhaft Y, et al. A comparative analysis of genetic variation in rootstocks and scions of old olivetrees - a window into the history of olive cultivation practices and past genetic variation. BMC Plant Biol. 2014;14:146.

15. Rallo L. In: Rallo L, Barranco D, Caballero JM, Del Río C, Martín A, Tous J, Trujillo I. (Eds.) Variedades de olivo en España. (eds) Junta deAndalucía, MAPA and Ediciones MundiPrensa, Madrid. 2005;14-44.

16. European Union Commission. Regulation EEC/2568/91 on the characteristics of olive oil and olive-residue oil and on relevant methods of analysis. Official Journal of the European Communities. 1991;L248:1-82.

17. Gutfinger T. Polyphenols in olive oils. J Am Oil Chem Soc. 1981;58(11):966-968.

18. Sefc KM, Lopes MS, Mendonça D, Rodrigues Dos Santos M, Laimer Da Câmara Machado M, Da Câmara Machado A. Identification of microsatellite loci in olive (Olea europaea L.) and their characterization in Italian and Iberian olivetrees. Mol Ecol. 2000;9:1171-1173.

19. De la Rosa R, James CM, Tobutt KR. Isolation and characterization of polymorphic SSRs in olive (Olea europaea L.) and their transferability to other genera in the Oleaceae. Mol Ecol Notes. 2002;2:265-267.

20. Carriero F, Fontanazza G, Cellini F, Giorio G. Identification of simple sequence repeats (SSRs) in olive (Oleaeuropaea L.). Theor Appl Genet. 2002;104:301-307.

21. Cipriani G, Marrazzo MT, Marconi R, Cimato A, Testolin R. Microsatellite markers isolated in olive (Olea europaea L.) are suitable for individual fingerprinting and reveal polymorphism within ancient cultivars. Theor Appl Genet. 2002;104:223-228.

22. Baldoni L, Cultrera NG, Mariotti R, Riccioloni C, Arcioni S, Vendramin GG, et al. A consensus list of microsatellite markers for olive genotyping. Mol Breed. 2009;24:213-231.

23. Lazović B, Adakalić M, Pucci C, Perović T, Bandelj D, Belaj A, et al. Characterizing ancient and local olive germplasm from Montenegro. Sci Hortic. 2016;209:117-123.

24. Peres AM, Baptista P, Malheiro R, Dias LG, Bento A, Pereira JA. Chemometric classification of several olive cultivars from Trás-os-Montes region (northeast of Portugal) using artificial neural networks. Chemometr Intell Lab Syst. 2011;105:65-73.

25. Rotondi A, Cultrera NG, Mariotti R, Baldoni L. Genotyping and evaluation of local olive varieties of a climatically disfavoured region through molecular,morphological and oil quality parameters. Sci Hortic. 2011;130(3):562-569.

26. Perica S, Patrick HB, L, Joseph HC, Agnes MSN, Christos D, Hening H, Stangoulis J. Foliar Boron Application Improves Flower Fertility and Fruit Set of Olive. Hortscience. 2001;36(4):714-716.

27. Erel R, Dag A, Ben-Gal A, Schwartz A, Yermiyahu U. Flowering and fruit set of olive trees in response to nitrogen, phosphorus, and potassium. J. Amer. Soc. Hort. Sci. 2008;133(5)639-647.

28. Barone E, Caruso T, Marra FP, Motisi A. Caratteristiche bimetriche di 25 cultivar di olivo del germoplasma Siciliano, Atti Convegno su 'Techniche norme e qualita in Olivicolura', Potenza. 1993;15-17.

29. Rosati A, Caporali S, Paoletti A. Floral Biology: Implications for Fruit Characteristics and Yield chapter in Olive Germplasm - The Olive Cultivation, Table Olive and Olive Oil Industry in Italy. INTECH. 2012;71-80.

30. Lazović B. Osobine ploda nekih sorti masline (Olea europaea). Poljoprivreda i šumarstvo/AgricultForest. 2001;47(3-4):15-25.

31. Miranović K. Elajografska proučavanja autohtonih sorti maslina u Bokokotorskom podrejonu. Poljoprivreda i šumarstvo/AgricultForest. 1979;XXIV(3-4):97-100.

32. Malheiro R, Casal S, Sousa A, de Pinho PG, Peres AM, Dias LG, et al. Effect of Cultivar on Sensory Characteristics, Chemical Composition, and Nutritional Value of Stoned Green Table Olives. Food and Bioprocess Technol. 2012;(5):1733-1742.

33. Di Bella G, Maisano R, La Pera L, Lo Turco V, Salvo F, Dugo G. Statistical characterization of Sicilian olive oils from the Peloritana and Maghrebian zones according to the fatty acid profile. J. Agric. Food Chem. 2007;55(16):6568-6574. 
34. Lazovic B, Bucar Miklavcic M, Adakalic M, Butinar B, Bester E. Characterization of oil of some olive varieties from Montenegro, Olivebioteq 2011, Chania, Crete, Greece, Proceedings. 2011;607-613.

35. Arcoleo G, Bivona G, Cacuiooi L, Corona O. Characterization of seven Sicilian virgin olive oils (O. europaea L.) from neglected varieties. Proc. Olivebioteq 2006;(2)461-465.

36. Hmmam I, Mariotti R, Ruperti B, Cultrera N, Baldoni L, Barcaccia G. Venetian olive (Olea europaea) disclosing the genetic identity of locally grown cultivars suited for typical extra virgin oil productions. Genet. Resour. Crop Evol. 2018 Springer online. DOI: 10.1007/s10722-018-0650-5.

37. Commission Implementing Regulation (EU), $n^{\circ}$ 299/2013: amending Regulation (EEC) $\mathrm{n}^{\mathrm{o}} 2568 / 91$ on the characteristics of olive oil and olive-residue oil and on the relevant methods of analysis. Official Journal of the European Union.

38. Baccouri O, Cerretani L, Bendini A, Caboni MF, Zarrouk M., Pirrone L, Ben Miled DD. Preliminary chemical characterization of Tunisian monovarietal virgin olive oils and comparison with Sicilian ones. Eur. J. Lipid Sci. Technol. 2007; (109):1208-1217.

39. Bucci R, Magri AD, Magri AL, Marini D, Marini F. Chemical authentication of extra virgin olive oil varieties by supervised chemometric procedures. J Agric Food Chem. 2002;50(3):413-418.

40. Ollivier D, Artaud J, Pinatel C, Durbec JP, Guérère M. Triacylglycerol and fatty acid compositions of French virgin olive oils. Characterization by chemometrics. J Agric Food Chem. 2003;51(19):5723-5731.

41. European Union Commission (2015). Commission Regulation No 1830/2015 of July 17 8 2015. Official Journal of the European Union, 2015;266:9-13.

42. Alonso-Salces RM, Héberger K, Holland MV, Moreno-Rojas J.M., Mariani C, Bellan G, et al. Multivariate analysis of NMR fingerprint of the unsaponifiable fraction of virgin olive oils for authentication purposes. Food Chemistry. 2010;118:956-965.

43. Aparicio R, Aparicio-Ruíz R. Authentication of vegetable oils by chromatographic techniques. J Chromatogr A. 2000;881(1-2):93-104.

44. Piscopo A, De Bruno A, Zappia A, Ventre C, Poiana M. Characterization of monovarietal olive oils obtained from mills of Calabria region (Southern Italy), Food Chem. 2016;213:313-318.

45. Giuffrè AM, Louadj L. Influence of Crop Season and Cultivar on Sterol Composition of Monovarietal Olive Oils in Reggio Calabria (Italy). Czech J Food Sci. 2013;31(3):256-263.

46. Mailer RJ, Ayton J, Graham K. The Influence of growing region, cultivar and harvest timing on the diversity of Australian olive oil. J Am Oil Chem Soc. 2010;87:877-884.

47. Pannelli G, Pandolfi S, Baldoni L, et al. Selezione e valorizzazione di olivi antichi in Umbria. In: Peoc.IV Conv. Naz. Piante Mediterranee. Matera. 2010;93-104. 